\title{
Differential Influence of No-Tillage and Precipitation Pulses on Soil Heterotrophic and Autotrophic Respiration of Summer Maize in the North China Plain
}

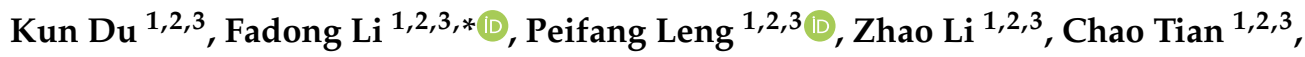 \\ Yunfeng Qiao ${ }^{1,2,3}$ and Zhaoxin $\mathrm{Li}^{1,2,3}$ (ID \\ 1 Key Laboratory of Ecosystem Network Observation and Modeling, Institute of Geographic Sciences and \\ Natural Resources Research, Chinese Academy of Sciences, Beijing 100101, China; \\ duk.17b@igsnrr.ac.cn (K.D.); lengpf.16b@igsnrr.ac.cn (P.L.); liz.18b@igsnrr.ac.cn (Z.L.); \\ tianc@igsnrr.ac.cn (C.T.); qiaoyf@igsnrr.ac.cn (Y.Q.); lizx.20b@igsnrr.ac.cn (Z.L.) \\ 2 Yucheng Shandong Agro-ecosystem National Observation and Research Station, Ministry of Science and \\ Technology, Yucheng 251200, China \\ 3 College of Resources and Environment, University of Chinese Academy of Sciences, Beijing 100049, China \\ * Correspondence: lifadong@igsnrr.ac.cn; Tel.: +86-010-64889530
}

Received: 26 November 2020; Accepted: 15 December 2020; Published: 20 December 2020

\begin{abstract}
It is important to strengthen the studies on the response of soil respiration components to tillage practices and natural precipitation in cropland. Therefore, soil heterotrophic respiration $\left(\mathrm{R}_{\mathrm{H}}\right)$ and autotrophic $\left(\mathrm{R}_{\mathrm{A}}\right)$ respiration were monitored by a root exclusion method in the North China Plain (NCP). The tillage practices included no-tillage (NT) and conventional tillage (CT), and the study periods were the summer maize growth stages in 2018 and 2019. $R_{H}, R_{A}$, soil water content and temperature were measured continuously for 113 days by an automatic sampling and analysis system. The soil $\mathrm{R}_{\mathrm{H}}$ values on bright days and rain-affected days were higher under NT in 2018 (14.22 and $15.06 \mathrm{~g} \mathrm{CO}_{2} \mathrm{~m}^{-2} \mathrm{~d}^{-1}$, respectively) than in 2019 (8.25 and $13.30 \mathrm{~g} \mathrm{CO}_{2} \mathrm{~m}^{-2} \mathrm{~d}^{-1}$, respectively). However, the $\mathrm{R}_{\mathrm{A}}$ values on bright days and rain-affected days were lower under NT in 2018 (4.74 and $4.97 \mathrm{~g} \mathrm{CO}_{2} \mathrm{~m}^{-2} \mathrm{~d}^{-1}$, respectively) than in 2019 (5.67 and $6.93 \mathrm{~g} \mathrm{CO}_{2} \mathrm{~m}^{-2} \mathrm{~d}^{-1}$, respectively). Moreover, NT decreased $R_{H}$ but increased $R_{A}$ compared to $C T$ in 2019. Compared to bright days, the largest increase in both $\mathrm{R}_{\mathrm{H}}$ and $\mathrm{R}_{\mathrm{A}}$ after rain pulses was under $\mathrm{CT}$ in 2019 (6.75 and $1.80 \mathrm{~g} \mathrm{CO}_{2} \mathrm{~m}^{-2} \mathrm{~d}^{-1}$, respectively). Soil water content and soil temperature were higher in 2018 than in 2019. Moreover, NT increased soil water content and decreased soil temperature on bright days compared to CT in 2019. Furthermore, soil temperature accounted for more variations in $R_{H}$ on bright days and rain-affected days, but soil water content had a greater influence on $R_{A}$ on bright days. However, after precipitation, higher soil water content decreased $R_{A}$ under NT in 2018, while soil water content was positively related to $R_{A}$ under $C T$ in 2019. This study determined the differential response of $R_{H}$ and $R_{A}$ to tillage practices and natural precipitation pulses, and we confirmed that excessively dry soil increases soil carbon loss after rain events in the NCP.
\end{abstract}

Keywords: soil respiration components; precipitation; no-tillage; automatic chamber; maize; North China Plain

\section{Introduction}

Soil respiration $\left(\mathrm{R}_{\mathrm{S}}\right)$ in cropland is a critical source of increasing atmosphere $\mathrm{CO}_{2}$ [1]. Soil respiration includes autotrophic respiration $\left(\mathrm{R}_{\mathrm{A}}\right)$ from the roots and rhizosphere communities, and heterotrophic 
respiration $\left(R_{H}\right)$ from soil microbes [2]. Moreover, $R_{H}$ is positively correlated with net primary productivity and is essential for assessing terrestrial carbon emissions to the atmosphere [3]. Conservation tillage practices, such as no-tillage (NT), tend to decrease $R_{H}$ and $R_{A}$ when compared to conventional tillage (CT) because of having a lower soil disturbance, which affects the soil water content and temperature and has a significant impact on $\mathrm{R}_{\mathrm{H}}$ and $\mathrm{R}_{\mathrm{A}}[4,5]$. However, it was reported that $R_{S}$ was higher under NT because less soil disturbance and soil water content is conserved under NT conditions [6,7]. Moreover, Liu et al. [8], Pareja-Sanchez et al. [6] and Salem et al. [7] suggested that the influence of NT on soil $\mathrm{CO}_{2}$ emissions varied with NT transformation time, soil properties, and climate. Thus, to further understand the response of soil $\mathrm{CO}_{2}$ emissions to NT, it is critical to explore the influence of short-term NT on $\mathrm{R}_{\mathrm{H}}$ and $\mathrm{R}_{\mathrm{A}}$.

Soil water content and soil temperature are key factors influencing $R_{H}$ and $R_{A}$ [9-11]. Precipitation is a critical environmental factor that causes significant changes in soil water content and temperature, leading to variations in $R_{S}$ [12]. Higher annual precipitation can lead to greater $R_{A}$ and $R_{H}$ due to increased soil water content $[9,11,13-15]$. Moreover, a rain pulse can increase soil $\mathrm{CO}_{2}$ emissions compared to emissions on bright and dry days $[16,17]$, and dry soil is more sensitive to rain events $[18,19]$. Many previous studies have reported that the precipitation manipulation method is valuable for climate change studies $[6,12,20,21]$. However, it can be problematic as it is difficult to simulate real precipitation scenarios and environment factors [22]. Therefore, less direct monitoring of $R_{S}, R_{H}$, and $R_{A}$ can be conducted under natural precipitation pulses and environment conditions [23]. As such, the response of $R_{H}$ and $R_{A}$ to natural precipitation pulses under different environment factors (i.e., soil water content and temperature) remains unknown.

The North China Plain (NCP) covers 1.445 million $\mathrm{km}^{2}$ and is an intensively cultivated agricultural area within China [24]. It is important to study and decrease the cropland soil $\mathrm{CO}_{2}$ emissions in a large area like the NCP. However, few studies have focused on the response of continuous daily $R_{H}$ and $R_{A}$ to short-term NT and natural precipitation pulses in the NCP. Therefore, we conducted an experiment to evaluate the performance of $\mathrm{R}_{\mathrm{H}}$ and $\mathrm{R}_{\mathrm{A}}$ for a summer maize field in the NCP. The objectives of this study are to (1) determine the influence of NT and precipitation pulses on $R_{H}$ and $R_{A}$, and (2) quantify the critical environment factors influencing the $\mathrm{R}_{\mathrm{H}}$ and $\mathrm{R}_{\mathrm{A}}$ of maize in the NCP. The hypotheses of this study are as follows: (1) the higher annual soil water content and temperature conditions in 2018 increased $R_{H}$ and $R_{A}$ on bright days and rain-affected days compared to those in 2019; (2) $R_{H}$ and $R_{A}$ are higher under NT than under CT in 2019; and (3) soil water content is more important in influencing $\mathrm{R}_{\mathrm{H}}$ and $\mathrm{R}_{\mathrm{A}}$ when compared with soil temperature in the NCP.

\section{Material and Methods}

\subsection{Site Description}

The study site is located at the Yucheng Shandong Agro-ecosystem National Observation and Research Station belonging to the Ministry of Science and Technology in the NCP ( $\left.36^{\circ} 50^{\prime} \mathrm{N}, 116^{\circ} 34^{\prime} \mathrm{E}\right)$. This area has a warm temperate continental monsoon climate. The long-term mean annual temperature is $13.3{ }^{\circ} \mathrm{C}$, and the mean annual precipitation is $559.8 \mathrm{~mm}[25,26]$. The primary local soil type is a calcaric fluvisol and the texture is silt loam (sand, 12\%; silt, 66\%; clay, 22\%) (Tu and Li, 2017; Zhao et al., 2018). In the $0-20 \mathrm{~cm}$ region, the soil $\mathrm{pH}$ (soil: water, $1: 5$ ) is 8.3 , total organic matter is $12.6 \mathrm{~g} \mathrm{~kg}^{-1}$, total $\mathrm{N}$ is $0.89 \mathrm{~g} \mathrm{~kg}^{-1}$, total $\mathrm{P}$ is $2.11 \mathrm{~g} \mathrm{~kg}^{-1}$, and total $\mathrm{K}$ is $21.4 \mathrm{~g} \mathrm{~kg}^{-1}$ [27].

\subsection{Field Management and Experimental Design}

The experimental treatments were established in October 2014 and included two tillage practices (NT and CT) under a randomized complete block design. The experimental plot area was $5 \mathrm{~m} \times 10 \mathrm{~m}$ (three replicates). The study was conducted during the summer maize growth periods in 2018 and 2019. The annual precipitation in 2018 and 2019 was 898.5 and $338.6 \mathrm{~mm}$, respectively. The annual 
temperature in 2018 and 2019 was 14.5 and $14.4^{\circ} \mathrm{C}$, respectively. The cumulative rainfall during the maize growth stage (from day 171 to 283) was $472.9 \mathrm{~mm}$ in 2018 and $220.3 \mathrm{~mm}$ in 2019 [27] (Figure 1).

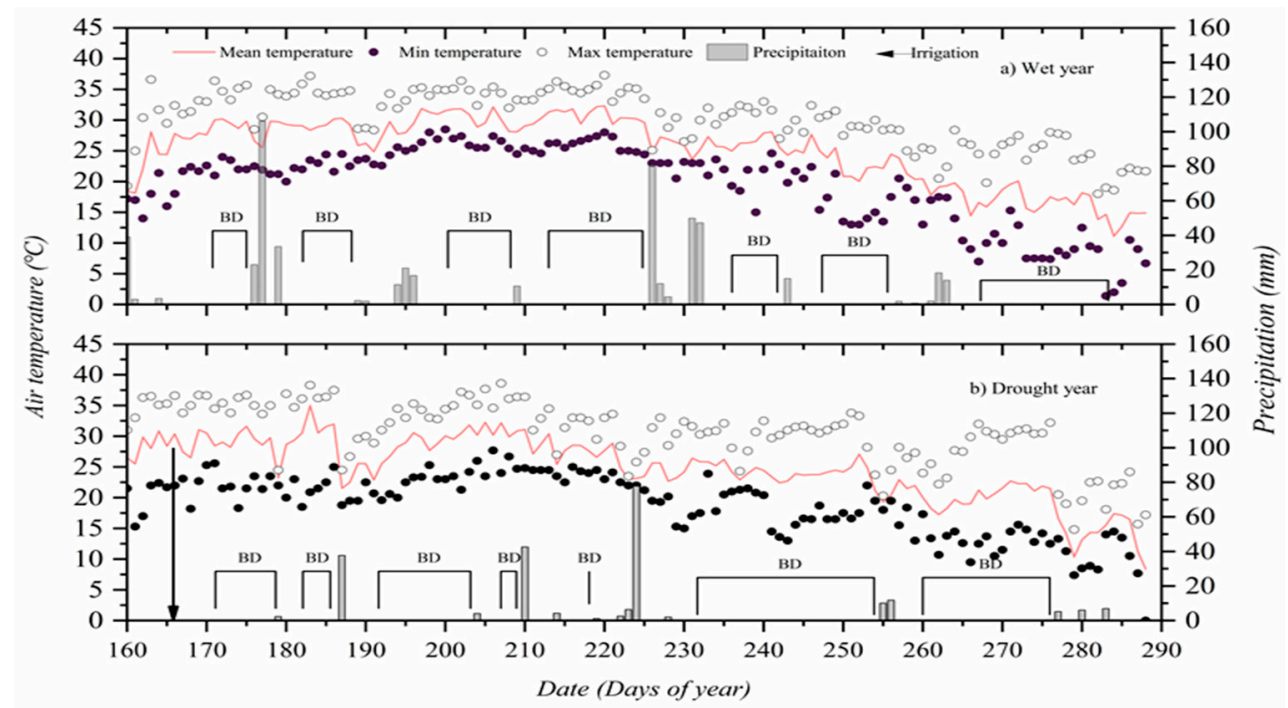

Figure 1. Mean, minimum, and maximum air temperature $\left({ }^{\circ} \mathrm{C}\right)$ and precipitation $(\mathrm{mm})$ during the maize growth stage (day 171-283) (a: 2018, b: 2019) at the Yucheng experimental station in the North China Plain. BD: bright days [27].

The former rotation crops of winter wheat (Triticum aestivum L.) and summer bean (Glycine max L.) were transformed into winter wheat-summer maize (Zea mays L.) in June 2018. Maize seeds (Denghai 605) were manually hole-sown in rows spaced $60 \mathrm{~cm}$ apart in mid-June. No irrigation was applied in 2018; however, $100 \mathrm{~mm}$ of irrigation was applied before seeding in late July 2019 because severe drought inhibited seed establishment. The total amount of nitrogen fertilization $\left(207 \mathrm{~kg} \mathrm{~N} \mathrm{ha}^{-1}\right)$ was applied via top-dressing after the rainfall in late July. During all maize growth periods, no plowing, additional irrigation, or wheat residue application was performed. All maize in the experimental plots was manually harvested on the same day in mid-October.

After the maize residues were removed, $100 \mathrm{~mm}$ of irrigation (from underground water) was applied to each plot. Tillage $(15 \mathrm{~cm})$ was applied with a rotary tiller only in the CT groups. Winter wheat (Jimai 22) was sown with a planting density of $262.75 \mathrm{~kg} \mathrm{ha}^{-1}$ in $20 \mathrm{~cm}$ rows. Base fertilization including nitrogen (as urea, $46.4 \%$ nitrogen content, $105 \mathrm{~kg} \mathrm{~N}^{-1}$ ), phosphorus $\left(750 \mathrm{~kg}_{2} \mathrm{O}_{5}\right.$ $\left.\mathrm{ha}^{-1}\right)$, and potassium $\left(160 \mathrm{~kg} \mathrm{~K}_{2} \mathrm{SO}_{4} \mathrm{ha}^{-1}\right.$ ) was applied in the sowing stage. The urea fertilization (105 kg N ha textsuperscript-1) was top-dressed when the first $100 \mathrm{~mm}$ of underground water was applied in March of the following year. A second irrigation $(100 \mathrm{~mm})$ was applied in mid-May. The winter wheat was harvested in the second week of June.

\subsection{Soil $\mathrm{CO}_{2}$ Sampling and Measurement}

Two transparent chambers $(0.5 \mathrm{~m} \times 0.5 \mathrm{~m} \times 0.5 \mathrm{~m})$ were installed in the centers of the plots in late May 2018. No plants were sown in the chambers. The collars of the two chambers were $5 \mathrm{~cm}$ deep (for $R_{S}$ ) [27] and $20 \mathrm{~cm}$ deep (for $R_{H}$ ). Furthermore, one row of maize was not planted at every side of the chamber for $R_{H}$ to achieve bare soil status in the $R_{H}$ chamber according to some previous studies $[28,29]$. Thus, according to the root exclusion method, the difference between $R_{S}$ and $R_{H}$ was $R_{A}$ (i.e., $R_{A}=R_{S}-R_{H}$ ) [28,30]. However, $R_{H}$ and $R_{A}$ data under $C T$ were not available because the instruments for $R_{H}$ were broken in the CT plot until the maize harvest in 2018. Therefore, this study only reported $\mathrm{R}_{\mathrm{H}}$ and $\mathrm{R}_{\mathrm{A}}$ in 2018-NT, 2019-NT and 2019-CT.

The automatically closed chambers and a Picarro G2508 analyzer (Picarro, Inc., Santa clara, USA; cavity ring-down spectroscopy) were used to sample and measure the $\mathrm{CO}_{2}$ mole fraction in all chambers [31]. The chamber brackets and plates were made of stainless steel and acrylic plastic, 
respectively. Two automatic push rods were installed to achieve an open or closed chamber. To ensure sufficient gas stirring in each chamber, two fans $(12 \mathrm{~V})$ operated in the two up and down diagonals of the chamber when the chamber was closed (image shown in Supplementary Information S1).

Chambers were left open to decrease the potential warming effect on soil when not sampling. Each chamber was closed for $200 \mathrm{~s}$ in turn every hour to sample the gas, except for 00:00 and 01:00 on one day (for other gas measurement). The sampled gas was transported to the analyzer through a $50 \mathrm{~m}$ long intake tube (inner diameter: $4.35 \mathrm{~mm})$ by an Edwards pump $(10 \mathrm{~L} / \mathrm{min}, 50 \mathrm{Mb}, 60 \mathrm{~Hz}$, Edwards Inc., Crawley, UK). The flow rates $\left(150 \pm 3 \mathrm{~mL} \mathrm{~min}^{-1} \mathrm{CO}_{2}\right)$ of the sampled gas were accurately controlled by a mass flow controller (FMA5400A, OMEGA Engineering, Inc., Norwalk, USA). $\mathrm{CO}_{2}$ concentration data were collected and recorded using a CR3000 data logger (Campbell Scientific, Inc., Logan, UT, USA).

The air pressure and temperature in the chamber were monitored using a barometric pressure transducer (Setra 278, Setra Systems Inc., MA, USA) and a Vaisala HMP155A sensor (Vaisala Inc., Helsinki, Finland), respectively.

The following equation was used to calculate the soil $\mathrm{CO}_{2}$ flux [32]:

$$
F=\frac{\mathrm{d} C / d t \times \rho \times h \times T_{0} \times P \times 10^{-3}}{T \times P_{0}}
$$

where $\mathrm{dC} / \mathrm{d} t\left(\mu \mathrm{L} \mathrm{L}^{-1} \mathrm{~h}^{-1}\right)$ is the linear variance of $\mathrm{CO}_{2}$ concentration during the sampling period $\left(\mathrm{R}^{2}>0.9\right), \rho\left(\mathrm{g} \mathrm{C} \mathrm{m}^{-3}\right)$ is the standard $\mathrm{CO}_{2}$ density at $T_{0}=273 \mathrm{~K}$ and $P_{0}=1013 \mathrm{hPa}, h(\mathrm{~m})$ is the chamber inner height, $T(\mathrm{~K})$ is the mean air temperature and $P(\mathrm{hPa})$ is the mean pressure during chamber closure. Data from 0 to $60 \mathrm{~s}$ were regarded as invalid data due to the last gas flush.

Wang et al. [33] suggested that soil respiration from 09:00 to 11:00 could represent the mean $\mathrm{CO}_{2}$ flux over $24 \mathrm{~h}$ in a single day. To increase the accuracy of the data and reduce the influence of instrument failure, we calculated the daily $\mathrm{R}_{\mathrm{H}}$ and $\mathrm{R}_{\mathrm{A}}$ using nine hours of data (averaged over $8 \mathrm{~h}$ intervals), including 01:00-04:00, 09:00-12:00, and 17:00-20:00. Our previous study indicated a strong positive correlation between soil respiration data measured at $9 \mathrm{~h}$ and $23 \mathrm{~h}\left(\mathrm{R}^{2}>0.99\right)$ and no significant difference between the data of the two methods [27].

The daily air temperature and precipitation data are shown in Figure 1. We selected the days from June 20 (day 171) to October 10 (day 283) as the study period. Rainy days and the three days following each rain event were denoted as rain-affected days (Figure 1). If it rained on consecutive days and the length of time between two precipitation events was less than three days, we assumed a single continuous rainfall event. All other days were denoted as bright days. The number of bright days and rain-affected days was 67 and 46 days in 2018, and 68 and 45 days in 2019, respectively. The mean $R_{H}$ and $\mathrm{R}_{\mathrm{A}}$ on bright days and rain-affected days were calculated using the daily soil $\mathrm{CO}_{2}$ flux for each weather type in every year.

\subsection{Auxiliary Measurements}

Vertical soil water content and temperature sensors (CS655, Campbell Scientific, Inc., Logan, UT, USA) were installed in the soil (to $30 \mathrm{~cm}$ depth) in each chamber. A linear calibration for the soil water content measurement was conducted using the drying method for every CS655 sensor. A datalogger CR1000 (Campbell Scientific, Inc., Logan, UT, USA) was used to collect data on soil water content, soil temperature, air pressure, and air temperature.

\subsection{Data Analysis}

Daily $\mathrm{R}_{\mathrm{H}}, \mathrm{R}_{\mathrm{A}}$, soil water content, and soil temperature data were calculated using $\mathrm{R}$ version 3.5.2 (R Foundation for Statistical Computing, Vienna, Austria). The effects of tillage practices were tested by one-way analysis of variance at $p=0.05$, using SPSS Statistics Client 19.0 (SPSS China, Beijing, China). The relationships between $R_{H}$ and $R_{A}$ with soil water content and soil temperature were examined 
using a stepwise linear regression with SPSS 19.0. Figures were drawn using OriginPro 8.0 (OriginLab Corporation, Northampton, MA, USA).

\section{Results}

\section{1. $R_{H}$ and $R_{A}$}

Both $R_{H}$ and $R_{A}$ varied significantly with tillage practices and maize growth stages (Figure 2). On bright days, the mean $R_{H}$ under NT was $72.18 \%$ higher in 2018 than in 2019; however, the mean $\mathrm{R}_{\mathrm{A}}$ was lower in 2018 than in 2019. Compared with CT, NT decreased $\mathrm{R}_{\mathrm{H}}$ by $1.21 \mathrm{~g} \mathrm{CO}_{2} \mathrm{~m}^{-2} \mathrm{~d}^{-1}$ but increased $R_{A}$ by $0.93 \mathrm{~g} \mathrm{CO}_{2} \mathrm{~m}^{-2} \mathrm{~d}^{-1}$ in 2019 (Table 1). Precipitation increased $R_{H}$ and $R_{A}$ when compared to bright days (Table 1). Comparing the two years, under NT, the increase in $R_{H}$ and $R_{A}$ after rainfall was higher in 2019 (by 5.05 and $1.26 \mathrm{~g} \mathrm{CO}_{2} \mathrm{~m}^{-2} \mathrm{~d}^{-1}$, respectively) than in 2018 (by 0.84 and $0.23 \mathrm{~g} \mathrm{CO}_{2} \mathrm{~m}^{-2} \mathrm{~d}^{-1}$, respectively) $(p<0.05)$ (Table 1). Similarly, the increase in $\mathrm{R}_{\mathrm{H}}$ and $\mathrm{R}_{\mathrm{A}}$ after precipitation was higher under CT (by 6.75 and $1.80 \mathrm{~g} \mathrm{CO}_{2} \mathrm{~m}^{-2} \mathrm{~d}^{-1}$, respectively) than under NT in 2019 (Table 1). Furthermore, the contribution of $R_{H}$ and $R_{A}$ on rain-affected days to the toral $R_{H}$ and $\mathrm{R}_{\mathrm{A}}$ under two weather conditions showed the relationship as 2019-CT $(53.14 \%, 52.87 \%)>2019-\mathrm{NT}$ $(51.62 \%, 44.72 \%)>2018-\mathrm{NT}(42.10 \%, 41.86 \%)$.

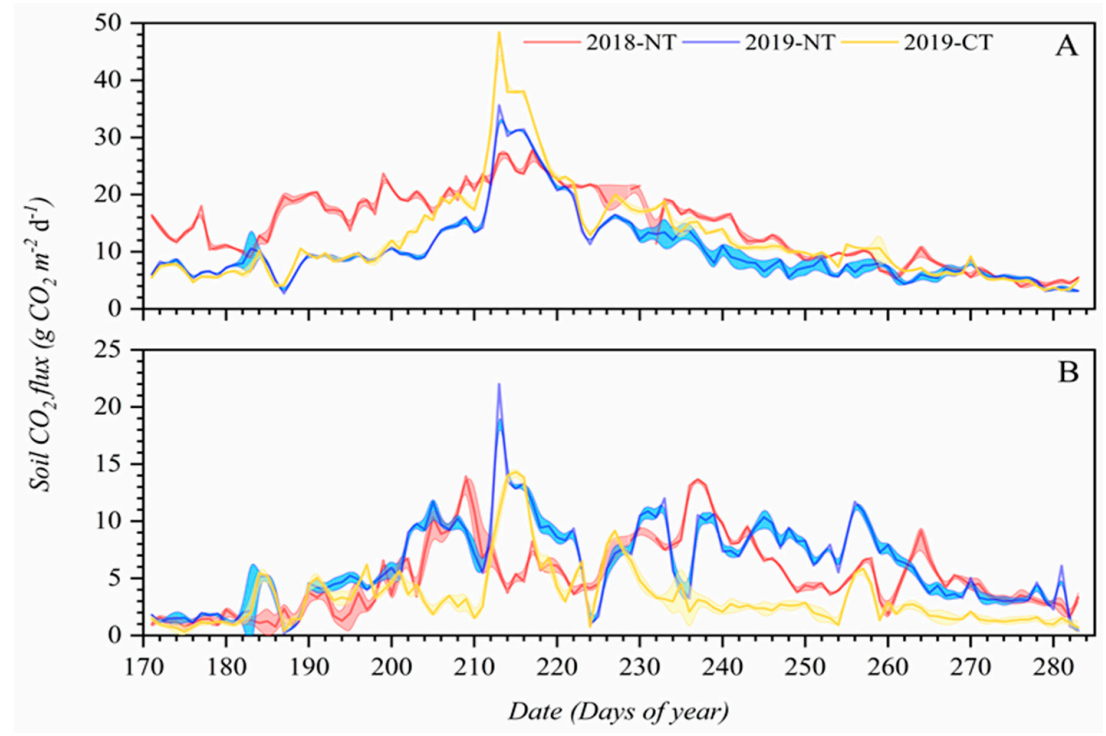

Figure 2. Daily soil heterotrophic respiration $\left(R_{H}\right)(A)$ and autotrophic respiration $\left(R_{A}\right)(B)$ in response to tillage practices during maize growth stages in 2018 and 2019.

Table 1. Mean $( \pm \mathrm{SE})$ daily $\mathrm{R}_{\mathrm{H}}$ and $\mathrm{R}_{\mathrm{A}}\left(\mathrm{g} \mathrm{CO}_{2} \mathrm{~m}^{-2} \mathrm{~d}^{-1}\right)$ on $\mathrm{BD}$ and RAD in response to tillage practices during maize growth stages in 2018 and 2019.

\begin{tabular}{ccccc}
\hline Weathers & Respiration & 2018-NT & 2019-NT & 2019-CT \\
\hline \multirow{2}{*}{$\mathrm{BD}$} & $\mathrm{R}_{\mathrm{H}}$ & $14.22 \pm 0.19 \mathrm{a}$ & $8.25 \pm 0.25 \mathrm{c}$ & $9.46 \pm 0.19 \mathrm{~b}$ \\
\cline { 2 - 5 } & $\mathrm{R}_{\mathrm{A}}$ & $4.74 \pm 0.10 \mathrm{~b}$ & $5.67 \pm 0.31 \mathrm{a}$ & $2.59 \pm 0.25 \mathrm{c}$ \\
\cline { 2 - 5 } RAD & $\mathrm{R}_{\mathrm{H}}$ & $15.06 \pm 0.19 \mathrm{~b}$ & $13.30 \pm 0.13 \mathrm{c}$ & $16.21 \pm 0.17 \mathrm{a}$ \\
\cline { 2 - 5 } & $\mathrm{R}_{\mathrm{A}}$ & $4.97 \pm 0.40 \mathrm{~b}$ & $6.93 \pm 0.32 \mathrm{a}$ & $4.39 \pm 0.30 \mathrm{~b}$ \\
\hline \multirow{2}{*}{$\mathrm{RAD}-\mathrm{BD}$} & $\mathrm{R}_{\mathrm{H}}$ & $0.84 \pm 0.07 \mathrm{c}$ & $5.04 \pm 0.17 \mathrm{~b}$ & $6.75 \pm 0.11 \mathrm{a}$ \\
\cline { 2 - 5 } & $\mathrm{R}_{\mathrm{A}}$ & $0.23 \pm 0.32 \mathrm{c}$ & $1.26 \pm 0.07 \mathrm{~b}$ & $1.80 \pm 0.06 \mathrm{a}$ \\
\hline \multirow{2}{*}{$\mathrm{RAD} /(\mathrm{BD}+\mathrm{RAD})$} & $\mathrm{R}_{\mathrm{H}}$ & $42.10 \%$ & $51.62 \%$ & $53.14 \%$ \\
\cline { 2 - 5 } & $\mathrm{R}_{\mathrm{A}}$ & $41.86 \%$ & $44.72 \%$ & $52.87 \%$ \\
\hline
\end{tabular}

Note: The same letters in a row indicate no significant difference between values ( $p>0.05)$; BD: bright days; RAD: rain-affected days. 


\subsection{Soil Water Content and Soil Temperature}

Tillage practices and precipitation had a significant influence on soil water content $(p<0.05)$ (Figure 3, Table 2). The mean soil water content was $0.28 \mathrm{~cm}^{3} \mathrm{~cm}^{-3}$ higher in 2018 than in 2019 . Compared to CT, NT increased mean daily soil water content on bright days by $0.61 \mathrm{~cm}^{3} \mathrm{~cm}^{-3}$ in $2019(p<0.05)$. Similarly, after precipitation, soil water contents were greater under NT. Moreover, under NT, the increase in soil water content derived from rain events was higher in 2018 compared to 2019 (Table 2).
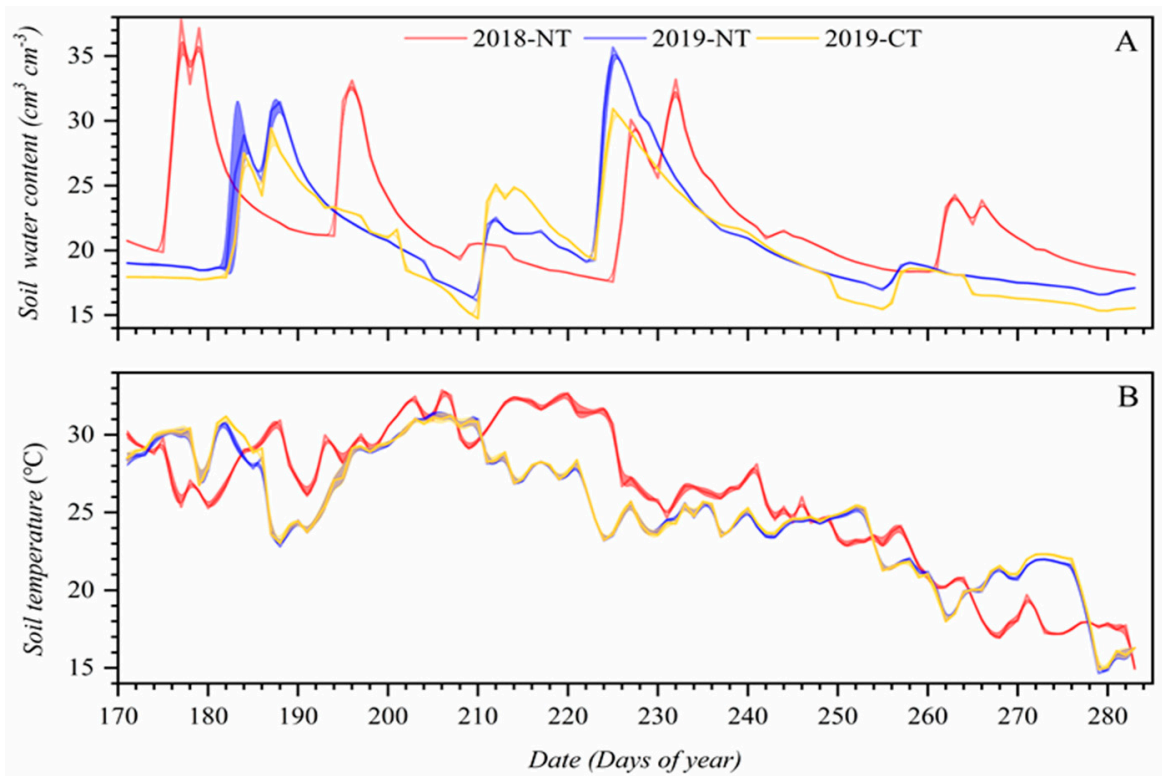

Figure 3. Soil water content (A) and soil temperature (B) in response to tillage practices during maize growth stages in 2018 and 2019.

Table 2. Mean $( \pm \mathrm{SE})$ soil water content $\left(\mathrm{cm}^{3} \mathrm{~cm}^{-3}\right)$ and soil temperature $\left({ }^{\circ} \mathrm{C}\right)$ in response to tillage practices in 2018 and 2019.

\begin{tabular}{ccccc}
\hline Treatments & Days & 2018-NT & 2019-NT & 2019-CT \\
\hline \multirow{3}{*}{ Soil water content } & BD & $20.34 \pm 0.09 \mathrm{a}$ & $20.06 \pm 0.11 \mathrm{~b}$ & $19.45 \pm 0.09 \mathrm{c}$ \\
\cline { 2 - 5 } & RAD & $25.08 \pm 0.19 \mathrm{a}$ & $21.92 \pm 0.05 \mathrm{~b}$ & $21.20 \pm 0.09 \mathrm{c}$ \\
\cline { 2 - 5 } & RAD-BD & $4.74 \pm 0.17 \mathrm{a}$ & $1.87 \pm 0.12 \mathrm{~b}$ & $1.75 \pm 0.15 \mathrm{~b}$ \\
\hline \multirow{3}{*}{ Soil temperature } & $\mathrm{BD}$ & $26.03 \pm 0.08 \mathrm{a}$ & $25.26 \pm 0.11 \mathrm{c}$ & $25.43 \pm 0.07 \mathrm{~b}$ \\
\cline { 2 - 5 } & RAD & $25.84 \pm 0.14 \mathrm{a}$ & $24.77 \pm 0.09 \mathrm{~b}$ & $24.82 \pm 0.05 \mathrm{~b}$ \\
\cline { 2 - 5 } & RAD-BD & $-0.19 \pm 0.21 \mathrm{~b}$ & $-0.50 \pm 0.13 \mathrm{a}$ & $-0.61 \pm 0.03 \mathrm{a}$
\end{tabular}

Note: The same letters in a row indicate no significant difference between values ( $p>0.05)$; BD: bright days; RAD: rain-affected days.

Mean soil temperature on bright days under NT was $0.77^{\circ} \mathrm{C}$ greater in 2018 than in $2019(p<0.05)$ (Table 2). NT decreased soil temperature by $0.17^{\circ} \mathrm{C}$ when compared with CT in $2019(p<0.05)$. After rain events, soil temperature decreased, and this decrease in soil temperature was greater under CT in $2019(p<0.05)$ (Table 2). Tillage practices had no significant influence on soil temperature after rain in $2019(p>0.05)$.

\subsection{Relationship between $R_{H}, R_{A}$ with Soil Water Content and Soil Temperature}

The stepwise analysis results showed that soil temperature was more critical in influencing $R_{H}$ on bright days and rain-affected days under NT in 2018; however, soil water content affected more 
variation in $R_{A}$ after precipitation under NT in 2018, and higher soil water content even decreased $R_{A}$ in 2018 (Table 3). Moreover, under NT, soil temperature had a more important effect on $R_{H}$ and $R_{A}$ when compared with soil water content in 2019 (Table 3). By contrast, under CT, soil water content contributed more variations in $R_{H}$ and $R_{A}$ on bright days in 2019 (Table 3).

Table 3. Multiple linear stepwise regression analysis between $\mathrm{R}_{\mathrm{H}}$ and $\mathrm{R}_{\mathrm{A}}$ with soil water content (SWC) and soil temperature (ST) in 2018 and 2019.

\begin{tabular}{cccccccc}
\hline \multirow{2}{*}{ Weathers } & Treatments & \multicolumn{3}{c}{$\mathbf{R}_{\mathbf{H}}$} & \multicolumn{3}{c}{$\mathbf{R}_{\mathbf{A}}$} \\
\cline { 3 - 8 } & & SWC & ST & Partial $\mathbf{R}^{2}$ & SWC & ST & Partial R $^{\mathbf{2}}$ \\
\hline \multirow{3}{*}{ BD } & 2018-NT & - & 0.915 & $0.834^{* *}$ & - & - & - \\
& $2019-\mathrm{NT}$ & 0.257 & 0.307 & $0.187^{*}$ & 0.354 & 0.454 & $0.794^{* *}$ \\
& $2019-\mathrm{CT}$ & 0.317 & - & $0.087^{* *}$ & 0.709 & - & $0.495^{* *}$ \\
& All & 0.152 & 0.786 & $0.394^{* *}$ & 0.270 & 0.046 & $0.062^{* *}$ \\
\hline \multirow{3}{*}{ RAD } & $2018-\mathrm{NT}$ & - & 0.792 & $0.618^{* *}$ & -0.330 & - & $0.090^{*}$ \\
& $2019-\mathrm{NT}$ & - & 0.544 & $0.280^{* *}$ & - & 0.386 & $0.129^{* *}$ \\
& $2019-\mathrm{CT}$ & 0.286 & 0.492 & $0.350^{* *}$ & 0.439 & - & $0.174^{* *}$ \\
& All & 0.105 & 0.554 & $0.327^{* *}$ & -0.058 & 0.253 & 0.048 \\
\hline
\end{tabular}

Note: ${ }^{*} p<0.05$; ${ }^{* *} p<0.01$. BD, bright days; RAD, rain-affected days.; "-" means not significant in the stepwise regression analysis.

\section{Discussion}

\subsection{Annual Variation in $R_{H}$ and $R_{A}$}

In accordance with the first hypothesis, under NT, $\mathrm{R}_{\mathrm{H}}$ on bright days was higher in 2018 than in 2019 (Table 1). This could be explained by the greater soil water content and temperature in 2018 (Table 2), and an increased effect of temperature on $R_{H}$ between the two years (Table 3), as Dossou-Yovo et al. and Poll et al. highlighted [11,34]. In contrast to the first hypothesis, under NT, $\mathrm{R}_{\mathrm{A}}$ on bright days was lower in 2018 when compared with 2019 in this study (Table 1), which is in line with the findings of Song et al. and Wang et al. $[23,35]$. This could be explained by the fact that roots grow deeper in dry soil to access water and enable plant growth [36], leading to higher $\mathrm{R}_{\mathrm{A}}$.

Similarly, under NT, after precipitation $\mathrm{R}_{\mathrm{H}}$ and $\mathrm{R}_{\mathrm{A}}$ were greater in 2018 when compared with those in 2019 due to higher soil water content after rain in 2018 (Tables 1 and 2). This is in line with our first hypothesis. This response was derived from the greater effect of soil temperature on $\mathrm{R}_{\mathrm{A}}$ on rain-affected days under NT in both years (Table 3). We suggest that the response of $R_{H}$ and $R_{A}$ to precipitation was limited by background respiration on bright days, as highlighted by the previous study [12].

Furthermore, $R_{H}$ and $R_{A}$ were higher on rain-affected days than on bright days (Table 1 ), similar to the findings of Refs. [37] and [17]. Austin et al., Gonsiorkiewicz et al., and Koncz et al. [16,17,38] indicated that precipitation pulses increased soil $\mathrm{CO}_{2}$ emissions because the additional soil water content after rain increases the soil microbial activity, organic substrate decomposition, and primes root effects. Moreover, the increase in $\mathrm{R}_{\mathrm{H}}$ and $\mathrm{R}_{\mathrm{A}}$ under NT was higher in 2019 than in 2018 (Table 1). It was reported that soil respiration in dry soil was more sensitive to added soil water content from precipitation and irrigation [13,18]. Concordantly, soil water content under NT was higher in 2018 than in 2019 (Table 2), leading to higher variations in $R_{H}$ and $R_{A}$ in 2019 (Table 1).

\subsection{Influence of No-Tillage and Precipitation on $R_{H}$ and $R_{A}$}

The second hypothesis was partly disproved because NT decreased $R_{H}$ on bright days in 2019 (Table 1), in line with the results of Ref. [34]. Almaraz et al. and Dossou-Yovo et al. [10,39] indicated that soil respiration under NT was lower than that under CT due to lower soil disturbance and the following less effusive oxygen. Furthermore, soil temperature was higher under $\mathrm{CT}$, and soil temperature was more important in influencing $R_{H}$ in this study (Table 3). In line with $R_{H}$ on bright days, $R_{H}$ after 
precipitation was lower under NT than under $\mathrm{CT}$ (Table 1). It was reported that the response of soil $\mathrm{CO}_{2}$ fluxes after rain events to tillage practices was affected by that on bright days [6]. Moreover, a higher soil temperature increased $R_{H}$ after precipitation in 2019 (Table 2, Table 3), as Dossou-Yovo et al. and Poll et al. $[10,11]$ suggested.

Ali et al. [20] highlighted that NT decreased $R_{A}$ due to the lesser soil disturbance, which led to lower root growth. By contrast, $\mathrm{R}_{\mathrm{A}}$ on bright days was greater under NT than under CT in 2019 (Table 1), in accordance with our second hypothesis. It was observed that soil water content on bright days was higher under NT (Table 2), resulting from the enhanced conservation of soil water content due to less soil disturbance [40,41]. Moreover, 2019 was a dry year (Figure 1). Besharat et al. [42] reported that dry soil conditions had a negative effect on root growth. Therefore, higher soil water content led to greater $\mathrm{R}_{\mathrm{A}}$ under NT (Table 1).

In 2019, the increase in $\mathrm{R}_{\mathrm{H}}$ and $\mathrm{R}_{\mathrm{A}}$ after rain pulses was higher under $\mathrm{CT}$ than under NT (Table 1), which could be explained by the possibility that the oxygen and $\mathrm{CO}_{2}$ exchange between soil and atmosphere was higher under $\mathrm{CT}$ due to the greater soil porosity $[15,43]$.

\subsection{Soil Water Content and Temperature and the Relationship with $R_{H}$ and $R_{A}$}

The soil water content-temperature relationship varies across many precipitation manipulation experiments $[6,20]$. In our previous study, we suggested that high air temperature led to greater soil temperature in 2018 when compared with that in 2019 (Figure 1) [27]. However, the soil water content was higher in 2018 than in 2019. This result indicates that air temperature was more influential on soil temperature after precipitation than soil water content in the two study years. Furthermore, the increase in soil water content after rain events was higher in 2018 than in 2019 (Table 2), suggesting that the soil water content was still insufficient after precipitation in 2019 , and this dry condition had a significant impact on soil $\mathrm{CO}_{2}$ emissions.

In this study, soil water content and temperature were highly correlated with $\mathrm{R}_{\mathrm{H}}$ and $\mathrm{R}_{\mathrm{A}}$ (Table 3), as observed by Silva et al. and Poll et al. [11,44]. Soil temperature was more important in influencing $R_{H}$ on bright days and rain-affected days under NT, but soil water content was more influential for $R_{H}$ under CT on bright days (Table 3). These results are partly in line with the third hypothesis. It was reported that soil disturbance was more intensive under $\mathrm{CT}$, and the following soil water evaporation was higher, leading to lower soil water content and greater soil temperature under CT $[4,5,41]$. Thus, the relationship of $R_{H}$ with soil temperature was more significant than that with soil water content under NT. By contrast, soil water content was the limiting factor when the soil was dry on bright days, as Balogh et al. and Eshel et al. $[18,45]$ suggested. However, it was suggested that soil temperature was a more important factor affecting $R_{H}$ when soil water content was increased after precipitation $[16,17]$.

In 2018, the precipitation was more than $40 \%$ higher than the mean rainfall during maize growth (Figure 1). Extra water in the soil led to less $\mathrm{O}_{2}$ and $\mathrm{CO}_{2}$ exchange between the soil and atmosphere, as many previous studies have reported $[9,16]$. Similarly, on bright days, soil temperature was more effective in limiting $R_{A}$ under NT in 2019. However, under CT in 2019, the soil water content was more effective in limiting $R_{A}$ on bright days and rain-affected days (Table 3). In 2019, the low soil water content was the limiting factor for root growth due to the significantly lower soil water content on bright days in 2019 (Table 2), and because the soil water content was insufficient even after rain events (Table 2).

Global climate change leads to altered soil water content and soil temperature conditions, and causes substantial variations in soil respiration due to frequent severe droughts and flooding [1] Therefore, it is essential to analyze the effect of annual environmental factors (such as soil water content and soil temperature) and tillage practices on soil $\mathrm{CO}_{2}$ emissions via $\mathrm{R}_{\mathrm{H}}$ and $\mathrm{R}_{\mathrm{A}}$. Moreover, continuous long-term observations of daily soil $\mathrm{CO}_{2}$ emissions are required to monitor every rain event in order to study the influence of NT on soil respiration in the NCP.

It was observed that $R_{H}$ and $R_{A}$ in the dry soil were more sensitive to added soil water content, and short-term NT accelerated the total soil respiration by increasing $R_{\mathrm{A}}$ compared to CT (Table 1). 
The summer maize cropland accounts for an important percent of the total farmland in the NCP [46]. Furthermore, irrigation was the only way to keep the soil water content and guarantee the corn yield of summer maize in the dry year in the NCP [25]. Therefore, we suggest that to decrease soil respiration in the NCP, cropland transform from tillage to no-tillage practices should not be conducted in the dry year, and we encourage proper but not excessive irrigation during summer maize growth stages under low annual precipitation conditions.

\section{Conclusions}

The influence of tillage practices and precipitation pulses on the $R_{H}$ and $R_{A}$ of summer maize was quantified using a root exclusion method. Continuous daily $\mathrm{R}_{\mathrm{H}}, \mathrm{R}_{\mathrm{A}}$, soil water content, and temperature were directly monitored across the maize growth stages with an in-situ automatic sampling and measurement system. It was observed that $R_{H}$ was higher on bright days and rain-affected days under NT in 2018 than in 2019 owing to the greater soil temperatures in 2018. However, under NT and both weather conditions, $R_{A}$ was lower in 2018 than in 2019. Similarly, NT decreased $R_{H}$ on bright days when compared with $\mathrm{CT}$ due to the lower soil temperature and higher soil water content under NT. Moreover, NT increased $R_{A}$ on bright days due to conserved soil water content under NT in 2019. The influence of tillage practices on $R_{H}$ and $R_{A}$ after precipitation was in line with that on bright days. Furthermore, the $R_{H}$ and $R_{A}$ values in dry soil, especially under $C T$ in 2019, were more sensitive to rain events. On bright days in 2019, soil temperature was more effective in accounting for the variations in $R_{H}$ and $R_{A}$ values under NT, but soil temperature was more effective under CT. After precipitation, soil temperature was more important in influencing $R_{H}$ under NT and CT. However, an excessive soil water content inhibited $R_{A}$ in 2018 , and soil water content was positively correlated with $R_{A}$ under CT in 2019. This study revealed the different responses of soil respiration components to altered rain events and tillage management. Long-term continuous observations are critical in order to understand the influence of precipitation and tillage practices on $R_{H}$ and $R_{A}$ in the NCP.

Supplementary Materials: The following are available online at http://www.mdpi.com/2073-4395/10/12/2004/s1.

Author Contributions: Conceptualization, F.L. and K.D.; methodology, K.D.; software, K.D. and P.L.; validation, F.L. and K.D.; formal analysis, F.L. and K.D.; investigation, K.D., P.L., Z.L. (Zhao Li) and Z.L. (Zhaoxin Li); resources, F.L. and Y.Q.; data curation, F.L., K.D., P.L., C.T. and Y.Q.; writing-original draft preparation, K.D.; writing-review and editing, F.L. and K.D.; supervision, F.L. and K.D. All authors have read and agreed to the published version of the manuscript.

Funding: This research was funded by the National Natural Science Foundation of China (No. 41771292, No. U1906219, No. 31170414), National Natural Science Foundation of China, and United Nations Environment Programme (No. 41761144053).

Acknowledgments: We would like to thank colleagues at the Yucheng experimental station for experimental support and constructive advice on this manuscript.

Conflicts of Interest: The authors declare no conflict of interest.

\section{References}

1. IPCC. Summary for Policymakers. In Climate Change 2013: The Physical Science Basis. Contribution of Working Group I to the Fifth Assessment Report of the Intergovernmental Panel on Climate Change; Cambridge University Press: Cambridge, UK, 2013.

2. Priwitzer, T.; Pajtík, J.; Konôpka, B.; Ištoňa, J.; Pavlenda, P. Carbon allocation in forest ecosystem-case studies from young pine stands. Lesn. Cas. For. J. 2009, 55, 239-250. [CrossRef]

3. Raich, J.W.; Potter, C.S. Global patterns of carbon dioxide emissions from soils. Glob. Biogeochem. Cycles 1995, 9, 23-36. [CrossRef]

4. Farhate, C.V.V.; De Souza, Z.M.; La Scala, N., Jr.; De Sousa, A.C.M.; Santos, A.P.G.; Carvalho, J.L.N. Soil tillage and cover crop on soil $\mathrm{CO}_{2}$ emissions from sugarcane fields. Soil Use Manag. 2019, 35, 273-282. [CrossRef]

5. Rutkowska, B.; Szulc, W.; Sosulski, T.; Skowronska, M.; Szczepaniak, J. Impact of reduced tillage on $\mathrm{CO}_{2}$ emission from soil under maize cultivation. Soil Tillage Res. 2018, 180, 21-28. [CrossRef] 
6. Pareja-Sanchez, E.; Cantero-Martinez, C.; Alvaro-Fuentes, J.; Plaza-Bonilla, D. Tillage and nitrogen fertilization in irrigated maize: Key practices to reduce soil $\mathrm{CO}_{2}$ and $\mathrm{CH}_{4}$ emissions. Soil. Tillage Res. 2019, 191, $29-36$. [CrossRef]

7. Salem, H.M.; Valero, C.; Angel Munoz, M.; Gil Rodriguez, M.; Silva, L.L. Short-term effects of four tillage practices on soil physical properties, soil water potential, and maize yield. Geoderma 2015, 237, 60-70. [CrossRef]

8. Liu, X.J.; Mosier, A.R.; Halvorson, A.D.; Zhang, F.S. The impact of nitrogen placement and tillage on NO, $\mathrm{N}_{2} \mathrm{O}, \mathrm{CH}_{4}$ and $\mathrm{CO}_{2}$ fluxes from a clay loam soil. Plant Soil 2006, 280, 177-188. [CrossRef]

9. de Araújo Santos, G.A.; Moitinho, M.R.; Silva, B.D.O.; Xavier, C.V.; Teixeira, D.D.B.; Corá, J.E.; Júnior, N.L.S. Effects of long-term no-tillage systems with different succession cropping strategies on the variation of soil $\mathrm{CO}_{2}$ emission. Sci. Total Environ. 2019, 686, 413-424. [CrossRef]

10. Dossou-Yovo, E.R.; Brueggemann, N.; Jesse, N.; Huat, J.; Ago, E.E.; Agbossou, E.K. Reducing soil $\mathrm{CO}_{2}$ emission and improving upland rice yield with no-tillage, straw mulch and nitrogen fertilization in northern Benin. Soil Tillage Res. 2016, 156, 44-53. [CrossRef]

11. Poll, C.; Marhan, S.; Back, F.; Niklaus, P.A.; Kandeler, E. Field-scale manipulation of soil temperature and precipitation change soil $\mathrm{CO}_{2}$ flux in a temperate agricultural ecosystem. Agric. Ecosyst. Environ. 2013, 165, 88-97. [CrossRef]

12. Pabst, H.; Gerschlauer, F.; Kiese, R.; Kuzyakov, Y. Land Use and Precipitation Affect Organic and Microbial Carbon Stocks and the Specific Metabolic Quotient in Soils of Eleven Ecosystems of Mt. Kilimanjaro, Tanzania. Land Degrad. Dev. 2016, 27, 592-602. [CrossRef]

13. Huxman, T.E.; Snyder, K.A.; Tissue, D.; Leffler, A.J.; Ogle, K.; Pockman, W.T.; Sandquist, D.R.; Potts, D.L.; Schwinning, S. Precipitation pulses and carbon fluxes in semiarid and arid ecosystems. Oecologia 2004, 141, 254-268. [CrossRef]

14. Knapp, A.K.; Hoover, D.L.; Wilcox, K.R.; Avolio, M.L.; Koerner, S.E.; La Pierre, K.J.; Loik, M.E.; Luo, Y.; Sala, O.E.; Smith, M.D. Characterizing differences in precipitation regimes of extreme wet and dry years: Implications for climate change experiments. Glob. Chang. Biol. 2015, 21, 2624-2633. [CrossRef]

15. Nielsen, U.N.; Ball, B.A. Impacts of altered precipitation regimes on soil communities and biogeochemistry in arid and semi-arid ecosystems. Glob. Chang. Biol. 2015, 21, 1407-1421. [CrossRef]

16. Gonsiorkiewicz, R.J.P.; Calonego, J.C.; Rosolem, C.A.; La Scala, N., Jr. Cover crop rotations in no-till system: Short-term $\mathrm{CO}_{2}$ emissions and soybean yield. Sci. Agric. 2018, 75, 18-26.

17. Koncz, P.; Balogh, J.; Papp, M.; Hidy, D.; Pinter, K.; Foti, S.; Klumpp, K.; Nagy, Z. Higher soil respiration under mowing than under grazing explained by biomass differences. Nutr. Cycl. Agroecosyst 2015, 103, 201-215. [CrossRef]

18. Eshel, G.; Lifschitz, D.; Bonfil, D.J.; Sternberg, M. Carbon exchange in rainfed wheat fields: Effects of long-term tillage and fertilization under arid conditions. Agric. Ecosyst. Environ. 2014, 195, 112-119. [CrossRef]

19. Liu, Y.; Hu, C.; Mohamed, I.; Wang, J.; Zhang, G.; Li, Z.; Chen, F. Soil $\mathrm{CO}_{2}$ Emissions and Drivers in Rice-Wheat Rotation Fields Subjected to Different Long-Term Fertilization Practices. Clean-Soil Air Water 2016, 44, 867-876. [CrossRef]

20. Ali, S.; Xu, Y.; Ahmad, I.; Jia, Q.; Ma, X.; Ullah, H.; Alam, M.; Adnan, M.; Daur, I.; Ren, X.; et al. Tillage and deficit irrigation strategies to improve winter wheat production through regulating root development under simulated rainfall conditions. Agric. Water Manag. 2018, 209, 44-54. [CrossRef]

21. Suseela, V.; Dukes, J.S. The responses of soil and rhizosphere respiration to simulated climatic changes vary by season. Ecology 2013, 94, 403-413. [CrossRef]

22. Beier, C.; Beierkuhnlein, C.; Wohlgemuth, T.; Penuelas, J.; Emmett, B.; Korner, C.; De Boeck, H.; Christensen, J.H.; Leuzinger, S.; Janssens, I.A.; et al. Precipitation manipulation experiments-challenges and recommendations for the future. Ecol. Lett. 2012, 15, 899-911. [CrossRef]

23. Song, H.; Yan, T.; Wang, J.; Sun, Z. Precipitation variability drives the reduction of total soil respiration and heterotrophic respiration in response to nitrogen addition in a temperate forest plantation. Biol. Fertil. Soils 2020, 56, 273-279. [CrossRef]

24. Han, H.F.; Ning, T.Y.; Li, Z.J.; Cao, H.M. The Ratio Of $\mathrm{CO}_{2}-\mathrm{C}$ Emission To Grain Yield In Summer Maize Cultivated under Different Soil Tillage And Straw Application Conditions. Exp. Agric. 2016, 53, 118-130. [CrossRef] 
25. Tu, C.; Li, F. Responses of greenhouse gas fluxes to experimental warming in wheat season under conventional tillage and no-tillage fields. J. Environ. Sci. 2017, 54, 314-327. [CrossRef]

26. Zhao, X.; Li, F.; Ai, Z.; Li, J.; Gu, C. Stable isotope evidences for identifying crop water uptake in a typical winter wheat-summer maize rotation field in the North China Plain. Sci. Total. Environ. 2018, 618, 121-131. [CrossRef] [PubMed]

27. Du, K.; Li, F.; Qiao, Y.F.; Leng, P.F.; Zhao., L.; Ge, J.P.; Yang, G. Influence of no-tillage and precipitation pulse on continuous soil respiration of summer maize affected by soil water in the North China Plain. Sci. Total Environ. 2020. accepted.

28. Chen, Z.; Xu, Y.; Fan, J.; Yu, H.; Ding, W. Soil autotrophic and heterotrophic respiration in response to different $\mathrm{N}$ fertilization and environmental conditions from a cropland in Northeast China. Soil Biol. Biochem. 2017, 110, 103-115. [CrossRef]

29. Hoffmann, M.; Wirth, S.J.; Bessler, H.; Engels, C.; Jochheim, H.; Sommer, M.; Augustin, J. Combining a root exclusion technique with continuous chamber and porous tube measurements for a pin-point separation of ecosystem respiration in croplands. J. Plant Nutr. Soil Sci. 2018, 181, 41-50. [CrossRef]

30. Mccalmont, J.P.; Mcnamara, N.P.; Donnison, I.S.; Farrar, K.; Clifton-Brown, J.C. Partitioning of ecosystem respiration of $\mathrm{CO}_{2}$ released during land-use transition from temperate agricultural grassland to Miscanthus x giganteus. Glob. Chang. Biol. Bioenergy 2017, 9, 710-724. [CrossRef]

31. Crosson, E.R. A cavity ring-down analyzer for measuring atmospheric levels of methane, carbon dioxide, and water vapor. Appl. Phys. B-Lasers Opt. 2008, 92, 403-408. [CrossRef]

32. Wang, K.; Liu, C.; Zheng, X.; Pihlatie, M.; Li, B.; Haapanala, S.; Vesala, T.; Liu, H.; Wang, Y.; Liu, G.; et al. Comparison between eddy covariance and automatic chamber techniques for measuring net ecosystem exchange of carbon dioxide in cotton and wheat fields. Biogeosciences 2013, 10, 6865-6877. [CrossRef]

33. Wang, K.; Zheng, X.; Pihlatie, M.; Vesala, T.; Liu, C.; Haapanala, S.; Mammarella, I.; Rannik, Ü.; Liu, H. Comparison between static chamber and tunable diode laser-based eddy covariance techniques for measuring nitrous oxide fluxes from a cotton field. Agric. For. Meteorol. 2013, 171-172, 9-19. [CrossRef]

34. Dossou-Yovo, E.R.; Brueggeman, N.; Ampofo, E.; Igue, A.M.; Jesse, N.; Huat, J.; Agbossou, E.K. Combining no-tillage, rice straw mulch and nitrogen fertilizer application to increase the soil carbon balance of upland rice field in northern Benin. Soil Tillage Res. 2016, 163, 152-159. [CrossRef]

35. Wang, Y.; Wang, D.; Shi, B.; Sun, W. Differential effects of grazing, water, and nitrogen addition on soil respiration and its components in a meadow steppe. Plant Soil 2020, 447, 581-598. [CrossRef]

36. Chen, F.; Yan, G.; Xing, Y.; Zhang, J.; Wang, Q.; Wang, H.; Huang, B.; Hong, Z.; Dai, G.; Zheng, X.; et al. Effects of $\mathrm{N}$ addition and precipitation reduction on soil respiration and its components in a temperate forest. Agric. For. Meteorol. 2019, 271, 336-345. [CrossRef]

37. Panosso, A.R.; Marques, J.; Jr Pereira, G.T.; La Scala, N., Jr. Spatial and temporal variability of soil $\mathrm{CO}_{2}$ emission in a sugarcane area under green and slash-and-burn managements. Soil Tillage Res. 2009, 105, 275-282. [CrossRef]

38. Austin, A.T.; Yahdjian, L.; Stark, J.M.; Belnap, J.; Porporato, A.; Norton, U.; Ravetta, D.A.; Schaeffer, S.M. Water pulses and biogeochemical cycles in arid and semiarid ecosystems. Oecologia 2004, 141, $221-235$. [CrossRef]

39. Almaraz, J.J.; Zhou, X.M.; Mabood, F.; Madramootoo, C.; Rochette, P.; Ma, B.L.; Smith, D.L. Greenhouse gas fluxes associated with soybean production under two tillage systems in southwestern Quebec. Soil Tillage Res. 2009, 104, 134-139. [CrossRef]

40. Helgason, B.L.; Walley, F.L.; Germida, J.J. Fungal and Bacterial Abundance in Long-Term No-Till and Intensive-Till Soils of the Northern Great Plains. Soil Sci. Soc. Am. J. 2009, 73, 120-127. [CrossRef]

41. Sainju, U.M.; Caesar-Tonthat, T.; Lenssen, A.W.; Barsotti, J.L. Dryland Soil Greenhouse Gas Emissions Affected by Cropping Sequence and Nitrogen Fertilization. Soil Sci. Soc. Am. J. 2012, 76, 1741. [CrossRef]

42. Besharat, S.; Nazemi, A.H.; Sadraddini, A.A. Parametric modeling of root length density and root water uptake in unsaturated soil. Turk. J. Agric. For. 2010, 34, 439-449.

43. Feiziene, D.; Feiza, V.; Karklins, A.; Versuliene, A.; Janusauskaite, D.; Antanaitis, S. After-effects of long-term tillage and residue management on topsoil state in Boreal conditions. Eur. J. Agron. 2018, 94, $12-24$. [CrossRef] 
44. de Oliveira Silva, B.; Moitinho, M.R.; De Araujo Santos, G.A.; Teixeira, D.D.B.; Fernandes, C.; La Scala, N., Jr. Soil $\mathrm{CO}_{2}$ emission and short-term soil pore class distribution after tillage operations. Soil Tillage Res. 2019, 186, 224-232. [CrossRef]

45. Balogh, J.; Papp, M.; Pinter, K.; Foti, S.; Posta, K.; Eugster, W.; Nagy, Z. Autotrophic component of soil respiration is repressed by drought more than the heterotrophic one in dry grasslands. Biogeosciences 2016, 13, 5171-5182. [CrossRef]

46. National Bureau of Statistics of China. Sown Area of Main Crops. Available online: https://data.stats.gov.cn/ easyquery.htm?cn=C01 (accessed on 9 December 2020).

Publisher's Note: MDPI stays neutral with regard to jurisdictional claims in published maps and institutional affiliations.

(C) 2020 by the authors. Licensee MDPI, Basel, Switzerland. This article is an open access article distributed under the terms and conditions of the Creative Commons Attribution (CC BY) license (http://creativecommons.org/licenses/by/4.0/). 